incrensed to five, and the legislature being at that time in session, he asked Hon. John Clark to introduce it. After the usual preliminaries it was passed, unanimously by the house and with a few opposition votes in the senate. It was ordered to take effect upon puolication, which was done immediately. In the meantime I sent a copy to Cook \& Dillon, at Davenport, and

- John F. Dillon drew a deed of adoption in accordance with the law. He caused it to be executed by the father and returned it to me. My wife and I executed it and I put it on record. It now stands as the first deed recorded under that law.

Ina Cook.

\title{
DR. SALTER'S CONTRIBUTIONS TO IOWA HISTORY.
}

We have had no more welcome contributor to the pages of The Anvals than the Rev. Dr. William Salter, the distinguished pastor of the Congregational Church of Burlington, Iowa. He has written much relating to the history of the Territory and State of Iowa, always with the bighest purpose in view, and his accuracy has never been questioned. $\mathrm{He}$ is a thorough and careful student and investigator, going to original sources, where such are accessible, and sparing no pains to verify any statement for which he is responsible. Whatever historical studies he may bequeath to coming generations will be accepted as the truth. His most considerable undertaking and one which will undoubtedly have a permanent place in the history of the West, is "The Life of James W. Grimes, Third Governor of Iowa." This has been widely accepted as an invaluable historical work, not only as a deserved tribute to one of the greatest American statesmen of his time, but as throwing much light upon Iowa history, when our State, as well as the Nation, were breaking away from the control of "the Slave Power," in all of which Governor Grimes bore a part that has made his name illustrious. But all of Dr. Salter's works possess great value to students of Iowa and western history. We have, therefore, secured the following bibliography of his writings, on Iowa history, from which the reader may readily locate and 
refer to any of them. They deserve a place in every public. library in Iowa:

1. Address in commemoration of the Two Hundredth Anniversary of the Discovery of Iowa, delivered before the Historical Society of Iowa, at Iowa City, June 23, 1873.

AnNats of Iowa, 1873. xi. 501-515.

2. The Western Border of Iowa in $1804,1806$.

Iowa His. Record. x: 71-'8.

3. The Eastern Border of Iowa in 1805-' 6 .

4. Dubuque in $\mathbf{1 8 2 0 .}$

Record. x. 107-121.

Record. xvi. 100-106:

5. Henry Dodge, Governor of the original Territory of Wisconsin (including Iowa, etc.). 1836-1838.

Record. v. 338-361; vi. 391-422, 445-467; vii. 101-119; viii. 251-267, 297-317; xiv. 289-309.

6. Letters of Henry Dodge to George W. Jones.

Ansals. 3d Series. iii. 220, 290, 384, 560.

7. James G. Edwards (founder of The Burlington Hawk-Eye, author of the cognomen "Hawkeyes" as applied to the people of Iowa): a sermon preached with reference to his death, August 10, 1851,--reprinted in part in Burlington Hawk-Eye, June 11, 1899.

8. James Clarke, 3d Governor of the Territory of Iowa. 1845-'6.

Record. iv. 1-12.

9. James W. Grimes, 3d|Governor of the State.

D. Appleton \& Co., N. Y. 1876. pp. 398. Record. viii. $337-360$.

10. The Progress of Religion in Iowa for Twenty-five Years (1833-1858). Burlington, June, 1858.

11. "The Death of the Soldier of the Republic," with reference to the death of Capt. C. C. Cloutman at the storming of Fort Donelson, Feb. 15, 1862. Ottumwa, May 18, 1862.

12. Rev. Benjamin A. Spaulding-sermon preached at his funeral. Ottumwa, April 2, 1867.

13. Memorial Discourse upon the Thirtieth Anniversary of the Denmark Congregational Association. Oct. 28, 1873.

14. Joseph W. Pickett, Superintendent of Home Missions in Southern Iowa and in the Rocky Mountains.

James Love, Burlingtón. $1880 . \quad$ pp. 150.

15. The Planting of Iowa-Address upon laying the corner-stone of Gaston Hali, Tabor College, Mills County, June 30, 1886.

16. Fiftieth Anniversary of the Congregational Church of Burlington. Nov. 25, 1888; reprint in part in Record. v. 212-222.

17. Augustus C. Dodge, U. S. Senator, 1848-1855.

Record. iii. 385-422. 
18. Mrs, Clara A. Dodge (A. C.)

Record, vii. 159-161.

19. Mrs. Elizabeth S. Grimes (J. W.)

Record. vii. 180-184.

20. Sermon in Commemoration of the Fiftieth Auniversary of the Congregational Association of Iowa, at Des Moines, May 21, 1890.

Minutes of the Association, 1890. pp. 48-59.

21. Major General John M. Corse.

Annals of Iowa. 3d Series. ii. 1-19, 105-145, 278-304.

22. Fiftieth Anniversary of the Adoption of the State Constitution by the People of Iowa Territory. August, 1896.

Annale. 3d Series. ii. 509-517.

23. Celebration of the Semi-Centennial of the State, at Burlington, October $1-8,1896$.

24. Alfred Hebard.

Annals. 3d Series. ii. 619-627.

Annals. 3d Series. iii. 47-52.

25. The Old People's Psalm, with Reminiscences of the Iowa Band, and: the Golden Wedding of the Rev. Dr. Ephraim Adams and Wife.

E. C. Gnahn, Burlington. 1895. pp. 24.

26. Commemoration of Fifty Years' Pastorate in Burlington, IowaApril 12, 1896.

E. C. Gnahn, Burlington. 1896. pp. 98 .

\section{DR. JOSIAH L. PICKARD.}

The news has gone forth that Dr. J. L. Pickard, expresident of the State University of Iowa, has recently sold? his home in Iowa City, and is about to leave the State. This is, indeed, sad news to the alumni of the University and. to all those who may be classed as workers in Iowa history.

After years of experience as an educator (first as principal of Platteville Academy; then as state superintendent of: Wisconsin, and finally as superintendent of the schools of: Chicago) he took up his residence in Iowa City as president: of the State University in 1878 . In 1887 he retired from. this position. But his work did not cease. Subsequentlyhe served on the school board of Iowa City, and continued to fill? the office of president of the Iowa State Historical Society: He was a member of the Bonrd of Curators of this Society.

As a student of the history of Iowa and of the West ine general, Dr. Pickard has been an inspiring leader. After 
Copyright of Annals of Iowa is the property of State of Iowa, by \& through the State Historical Society of Iowa and its content may not be copied or emailed to multiple sites or posted to a listserv without the copyright holder's express written permission. However, users may print, download, or email articles for individual use. 